\title{
Area vulnerability to flooding in Rangkasbitung District and its surroundings, Lebak Regency, Province of Banten
}

\author{
Chindy Octavia ${ }^{1 *}$, and Kuswantoro Marko ${ }^{1}$ \\ ${ }^{1}$ Department of Geography, Faculty of Mathematic and Natural Sciences, Universitas Indonesia, \\ Depok, Indonesia
}

\begin{abstract}
There are frequent floods in Lebak Regency, especially in the central city, i.e., Rangkasbitung and its surroundings, which is detrimental to local society. In the last five years, there has been 43 times the flood disaster. The problem of this flooding has not been entirely resolved, although there are indications of an increase in frequency, duration, and distribution in the study area. This study discusses the vulnerability of the area to flooding based on social, economic, and physical characteristics. KMeans Clustering is used to analyze the level of vulnerability for each village from 39 villages in Rangkasbitung, Cibadak, and Kalanganyar Districts. The results showed that the vulnerability level to flooding is dominated by a moderate level spread in the center of the study area. In contrast, the high level of vulnerability spread in the eastern and western parts of the study area. These results can be used as a basis for determining the flood risk areas in future studies.
\end{abstract}

\section{Introduction}

Floods are one of the natural disasters that occur very often globally and are very detrimental because they cause many lives and property losses every year [1-4]. The most shocking flood disasters occurred, not only in Indonesia but all over the world $[2,5]$. Indonesia is one of the countries that cannot get away from disasters, especially flood that occurs almost every year in some big cities. The cost of damage tends to increase every year. During the last 30 years, Asia-Pacific has been the most affected by flooding in the economic sector and casualties, especially in 2010 and 2011 [6]. In 2010, 178 million people were affected by floods. That brings the total loss from the floods from 1998 to 2010 above $\$ 40$ billion. According to the National Disaster Management Agency of the Republic of Indonesia (BNPB), in 2019, Indonesia experienced floods for 732 times. The province that often gets flooded is Central Java, 732 times. Meanwhile, from 2020 until now, Indonesia has experienced floods of 607 times. The province frequently affected by flooding was Central Java, with 235 times, while

\footnotetext{
* Corresponding author: kuswantoro@sci.ui.ac.id
} 
West Java was in the second position, 94 times, and the lowest was Aceh Province with one flood[23].

The Ciujung Watershed, which is one of the largest watersheds in Banten Province, covered three regency areas, i.e., Serang, Lebak, and Pandeglang [7] is one of the regions with relatively high flood potential [7]. In 2019, the central area of Lebak Regency, i.e., Rangkasbitung, Cibadak, and Kalanganyar Districts, experienced a flood disaster caused losses in many sectors. The high rainfall intensity, i.e., $115 \mathrm{~mm}$ in three hours, has inundated the settlement, business areas, and main roads with flood depth $20-50 \mathrm{~cm}$ [8].

This study will analyze the flood vulnerability based on the study area's physical, social, and economic characteristics. Although the National Disaster Management Authority Republic of Indonesia (BNPB) has mapped the vulnerability area, it is still for the general area. This study offers a new approach on how to analyze the vulnerability level for each village units. For that, K-Means Clustering is as conducted to identify the villages' level of vulnerability to flooding. Some researchers such as Xu, et al. [10-15]. In the end, this study can be useful for stakeholders, particularly for the policymakers of the Lebak Regency, to reduce the losses due to floods and to facilitate the mitigation efforts.

\section{Method}

\subsection{Study area}

This study is conducted in the central of Lebak Regency, including Rangkasbitung, Cibadak, and Kalangayar District, located at $6^{\circ} 21^{\prime} 42.28^{\prime \prime S}$ and $106^{\circ} 16.4^{\prime} 4.05^{\prime \prime}$ E. The study area has a relatively flat terrain between 30-60 meters above sea level (m.a.s.l). Its climate is tropical, with the minimum and maximum temperature are $22,1^{\circ} \mathrm{C}$ and $33,1^{\circ} \mathrm{C}$, respectively [16]. 


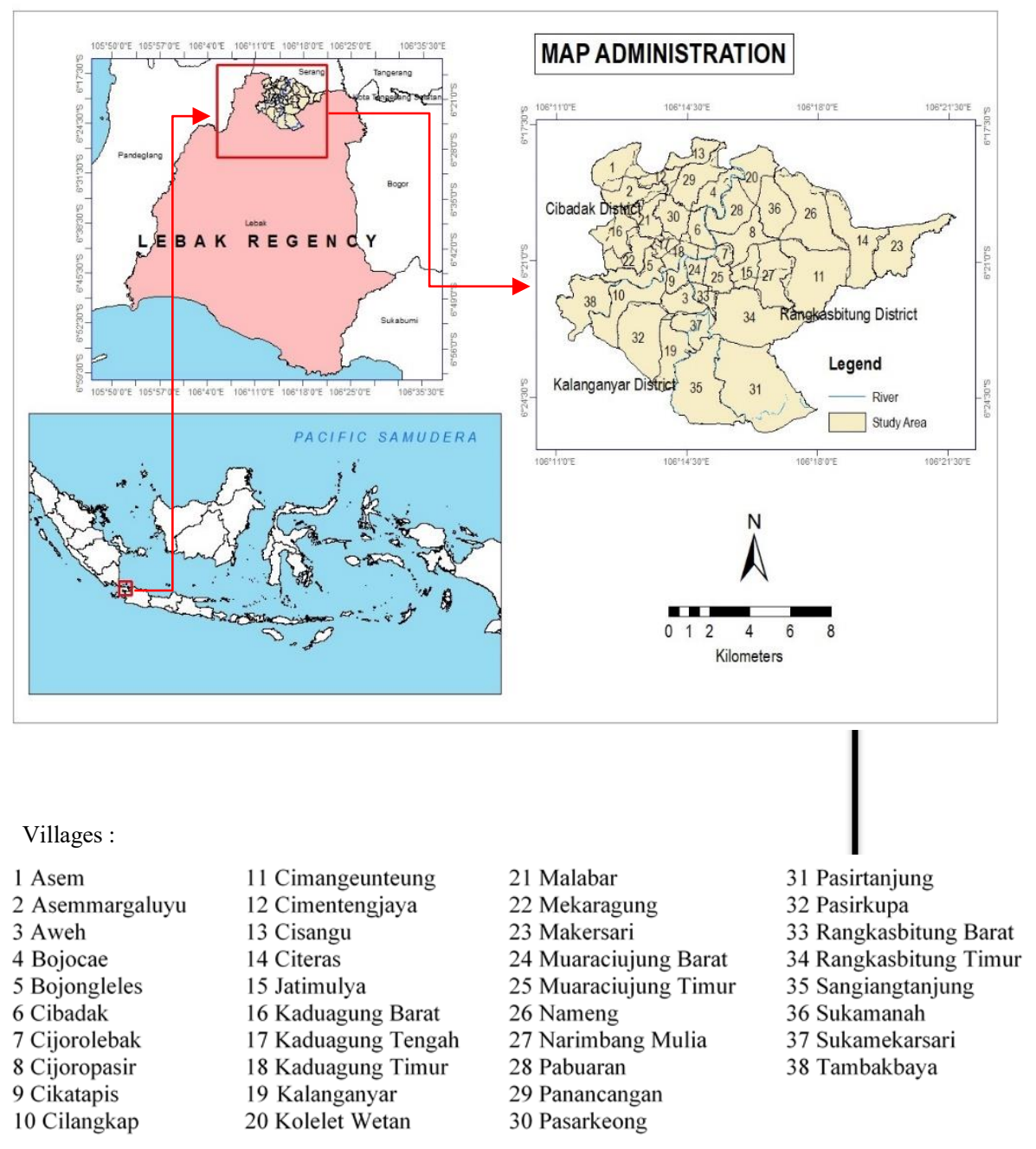

\subsection{Flood hazard level}

According to National Disaster Management Authority Republic of Indonesia (BNPB), the flood hazard in question is the potential for a series of events to arise and cause damage or loss. Meanwhile, flood-prone areas are areas with frequent natural disasters or natural disasters that cause economic, physical, and social losses

Therefore, the map used to create the flood hazard map produced comes from the flood hazard map, Lebak, Banten, sourced from BNPB. The classification made for flood-prone maps by BNPB is land use, land system, rainfall, and the occurrence of flood events (Figure $3)$. 
Flooding that occurs in this part of the moderate Ciujung Hilir River Watershed is something that often occurs in every rainy season or at the beginning of the year. This is because of high rainfall and the flat topography around the lower Ciujung Watershed. However, not all villages on the moderate Ciujung Watershed have a low topography.

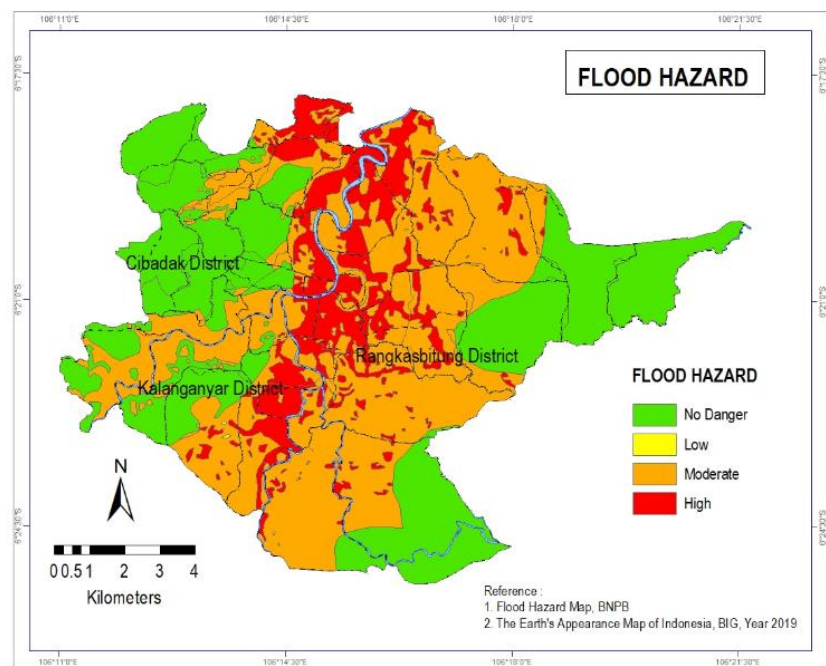

Fig. 2. Flood hazard level in the study area

\subsection{Material and Methods}

In general, the stages of the research are carried out by the following Figure. The area's vulnerability to flooding is based on physical conditions, i.e., the density of buildings and infrastructure, social conditions, population density, the population of old age, and the population aged under five. In contrast, the economic condition is the area of productive land and informal sector workers. The method used for the area's vulnerability to flooding is the K-Means Cluster method. 


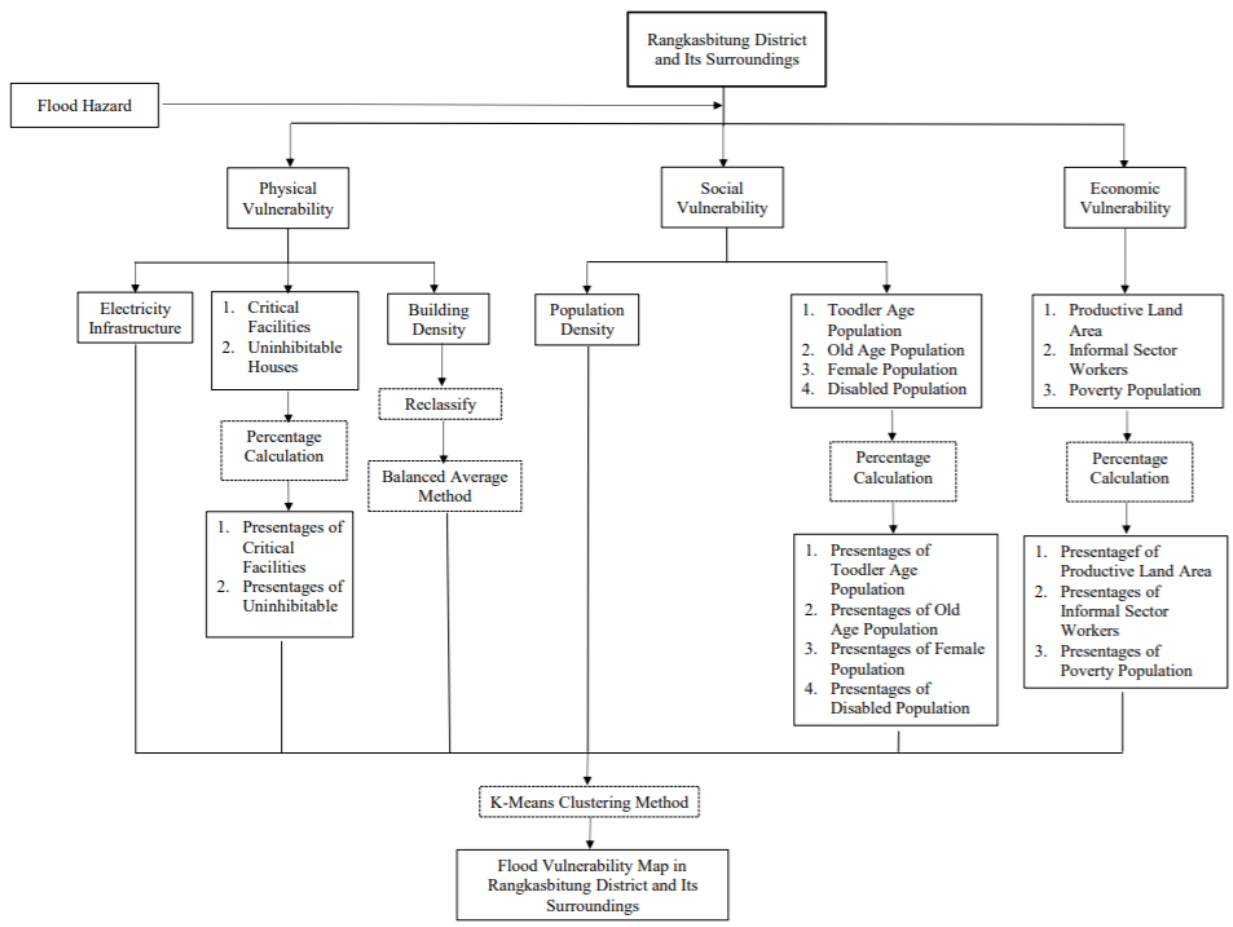

Meanwhile, to determine the flood hazard level, it is obtained from BNPB data on flood hazard maps in Lebak Regency. According to ArcMap 10.4 software, the research area was georeferenced and digitized and then processed by a balanced average method to obtain each village / sub-district flood hazard level in the research area.

\subsection{Data Required}

The variables used for flood vulnerability vulnerability from several parameters can be seen in table 1. Each parameter has a different unit. So, the method used is the K-Means Cluster.

Table 1. Variables

\begin{tabular}{|c|l|l|}
\hline \multicolumn{1}{|c|}{ Variabel } & \multicolumn{1}{|c|}{ Parameter } & \multicolumn{1}{c|}{ Units } \\
\hline \multirow{4}{*}{ Physical Vulnerability } & Building Density & Building/Ha \\
\cline { 2 - 3 } & Electricity Infrastructure & Unit \\
\cline { 2 - 3 } & Uninhabitable House & Building/Ha \\
\cline { 2 - 3 } & Critical Facilities & Unit \\
\hline \multirow{4}{*}{ Social Vulnerability } & Toodler Age Population & Persent (\%) \\
\cline { 2 - 3 } & Old Age Population & Persent (\%) \\
\cline { 2 - 3 } & Disabled Population & Person/Ha \\
\cline { 2 - 3 } & Female Population & Person/Ha \\
\hline Economic Vulnerability & Productive Land Area & Hektar (Ha) \\
\cline { 2 - 3 } & Informal Sector Workers & Person/Ha \\
\cline { 2 - 3 } & Population Poverty & Family Card \\
\hline
\end{tabular}




\subsection{Data processing}

In processing data in this study using ArcMap 10.4 software, IBM SPSS Statistics 26, and Microsoft Excel 2010. The following are the steps in processing each variable in order to obtain the results of regional vulnerability to floods in Cibadak, Rangkasbitung, and Kalanganyar districts:

\subsubsection{Balanced average method}

The level of productive land area per village / sub-district is determined using a balanced average formula for each village in the study area, namely the formula by Susilowati \& Santita 2006. [18]:

$$
\mathrm{H}=\frac{\sum \mathrm{An} \times \mathrm{H} n}{\text { Atotal }}
$$

Where: $\mathrm{H}=$ Equilibrium average runoff coefficient, $\mathrm{An}=\mathrm{Area}$ at the productive land level, $\mathrm{Hn}=$ Score value on productive land level (High: 3, Medium: 2, Low: 1), A total=The area of the village in the research area.

\subsubsection{Social, economic, and physical conditions}

In calculating the percentage of social, economic, and physical parameters using Microsoft Excel 2007 software. Meanwhile, maps in each social, economic, and physical parameter were done using ArcMap 10.4 software.

Table 2. Data Processing

\begin{tabular}{|c|c|c|}
\hline No. & Parameter & Data Processing \\
\hline 1. & Building Density & $\begin{array}{l}\text { From of raster classified using the reclassification feature in } \\
\text { ArcMap } 10.4\end{array}$ \\
\hline 2. & Population Density & $\begin{array}{l}\text { Population data compared to the area of a village in units of } \\
\text { people/ha }\end{array}$ \\
\hline 3. & Productive Land Area & $\begin{array}{l}\text { Earth map data devired from the Rupa Bumi Map of Indonesia } \\
\text { at a scale of 1: } 25.000 \text { by classifying land cover as productive } \\
\text { land }\end{array}$ \\
\hline 4. & $\begin{array}{l}\text { Precentage Toddler, } \\
\text { Old, Female, and } \\
\text { Disabled Population }\end{array}$ & $=\frac{\text { Data of paramters population }}{\text { total population }} \times 100 \%$ \\
\hline 5. & $\begin{array}{l}\text { Precentage } \quad \text { Critical } \\
\text { Facilities }\end{array}$ & $=\frac{\text { Data of critical facilities every village }}{\text { total all critocal facilities in area study }} \times 100 \%$ \\
\hline
\end{tabular}




\begin{tabular}{|c|l|l|}
\hline 6. & $\begin{array}{l}\text { Percentage Poverty } \\
\text { Population }\end{array}$ & $=\frac{\text { Data of poverty population }}{\text { total of family card }} \times 100 \%$ \\
\hline 7. & $\begin{array}{l}\text { Percentage } \\
\text { Uninhabitable House }\end{array}$ & $=\frac{\text { Data of uninhabitable house }}{\text { total of house in a village }} \times 100 \%$ \\
\hline 8. & $\begin{array}{l}\text { Percentage Informal } \\
\text { Sector Workers }\end{array}$ & $=\frac{\text { Data of paramters population }}{\text { total of informal sector } \text { workers in area study }} \times 100 \%$ \\
\hline 9. & Electrical Infrastructure & $\begin{array}{l}\text { From data on the precense or absence of electricity as strees } \\
\text { lighting in evert village }\end{array}$ \\
\hline
\end{tabular}

\subsubsection{Level of vulnerability}

$\mathrm{K}$-means algorithm is one of the basic clustering techniques used in many data mining applications. This unsupervised algorithm is usually used in data mining and pattern recognition. Aiming at minimizing cluster performance index, square-error, and error criterion are foundations of this algorithm. To seek the optimizing outcome, this algorithm tries to find $\mathrm{K}$ divisions to satisfy a certain criterion. $\mathrm{K}$-means algorithm based on dividing is a kind of cluster algorithm and has advantages of briefness, efficiency, and celerity by Li and $\mathrm{Wu}$. [10, 12]. The software used in data processing with the K-Means Clustering method is IBM SPSS Statistics 26. Here are the steps in processing the data:

a) Perform data standardization. The data used in this study have different units, such as souls/ha, buildings/ha, or percent. Therefore, it is necessary to take standardization steps or transformations of relevant parameters into the form of z-scores. The step that must be done is to use descriptive features.

b) Using the descriptive feature, it will also display the average data and the standard deviation of the parameters used as a search for the average value of each parameter.

c) Perform the clustering process. The clustering process is carried out using the $\mathrm{K}$ Means Cluster Analysis feature. In this case, determine the number of clusters desired. This study uses seven clusters, which are regrouped into three classes. The output of the area's vulnerability to flooding can be grouped into low, moderate, and high for each village in the study area $[19,20]$.

\section{Results and discussion}

\subsection{Social, economic and physical conditions}

Physical, social, and economic data are obtained from the Central Bureau of Statistics (BPS) in each sub-district. However, data on poverty is obtained from the social service agency, for building density from infimap and for uninhabitable houses from the housing and defense agency of Lebak Regency. After that, the data displayed on the map has been made into a percent according to what is described in Table 2.

The physical vulnerability consists of building density, uninhabitable houses, electricity infrastructure, and critical facilities. Of all the parameters of physical vulnerability have different levels of vulnerability. From all physical parameters, it can be seen that the research area has a low dominant physical vulnerability (Figure 4). 
The social vulnerability consists of population density, old age population, toddler age population, disabled population, and female population. Of all the parameters of social vulnerability have different levels of vulnerability (Figure 5).

The economic vulnerability consists of the area of productive land, population poverty, and informal sector workers. All parameters of economic vulnerability have different levels of vulnerability (Figure 6).

Productive land area is the area of land used by the community for productive activities such as rice fields, gardens, plantations, moor, and fishponds. The area of productive land is expressed in units of hectares (ha). Assessment of productive land area is based on the criteria of the Head of BNPB Regulation Number 02 (2012: 34).
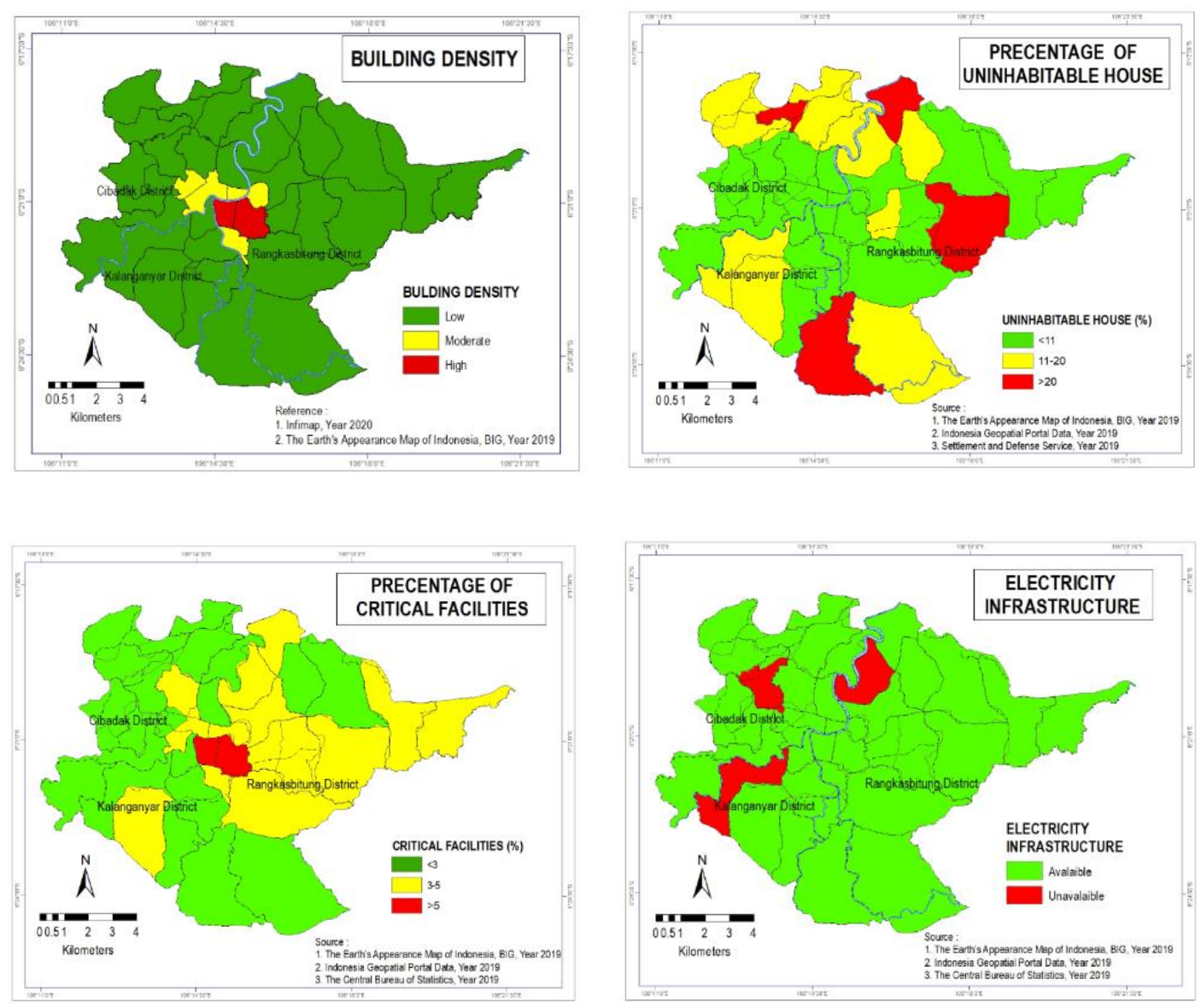

Fig. 4. Parameters of physical vulnerability 

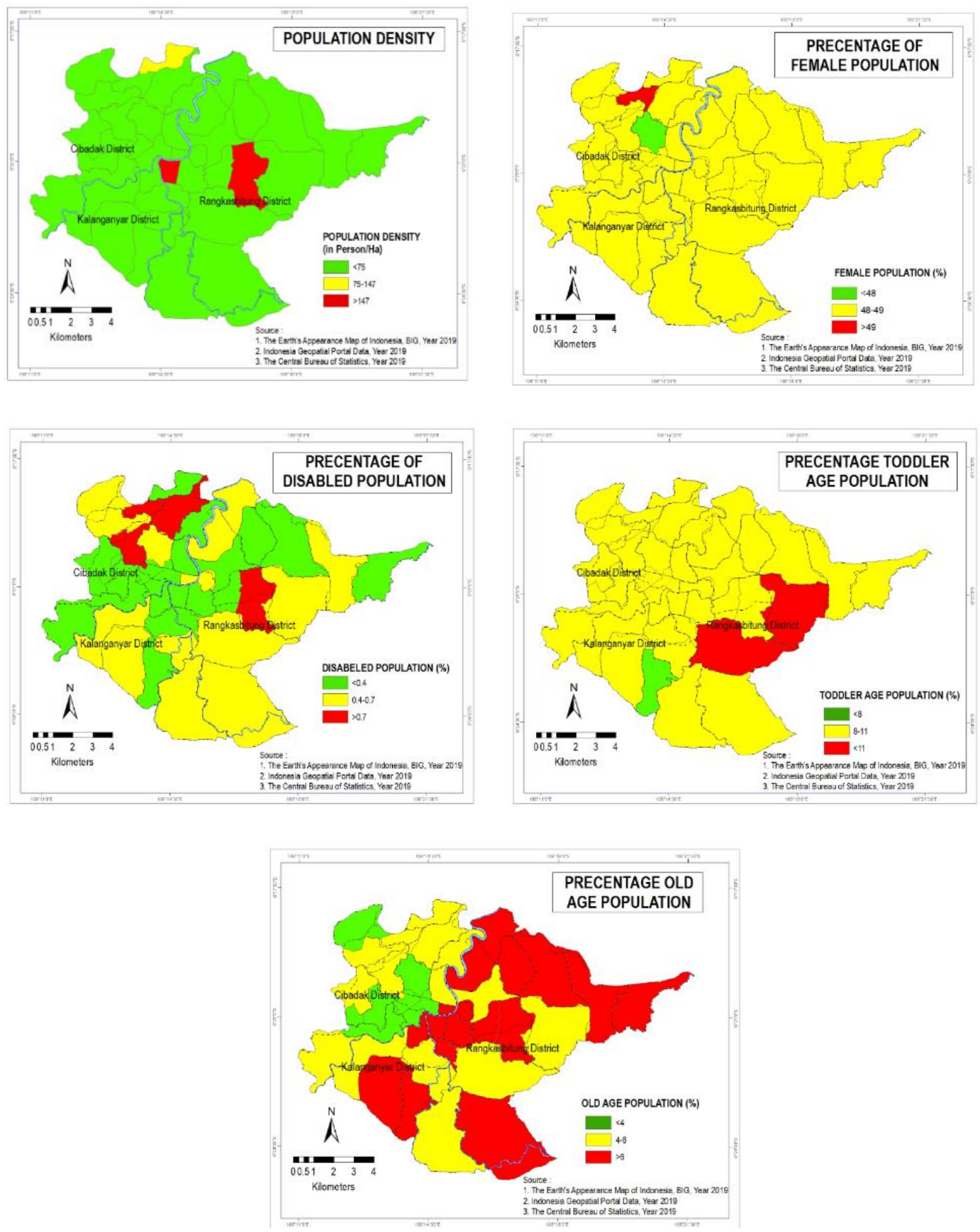

Fig. 5. Parameters of social vulnerability 

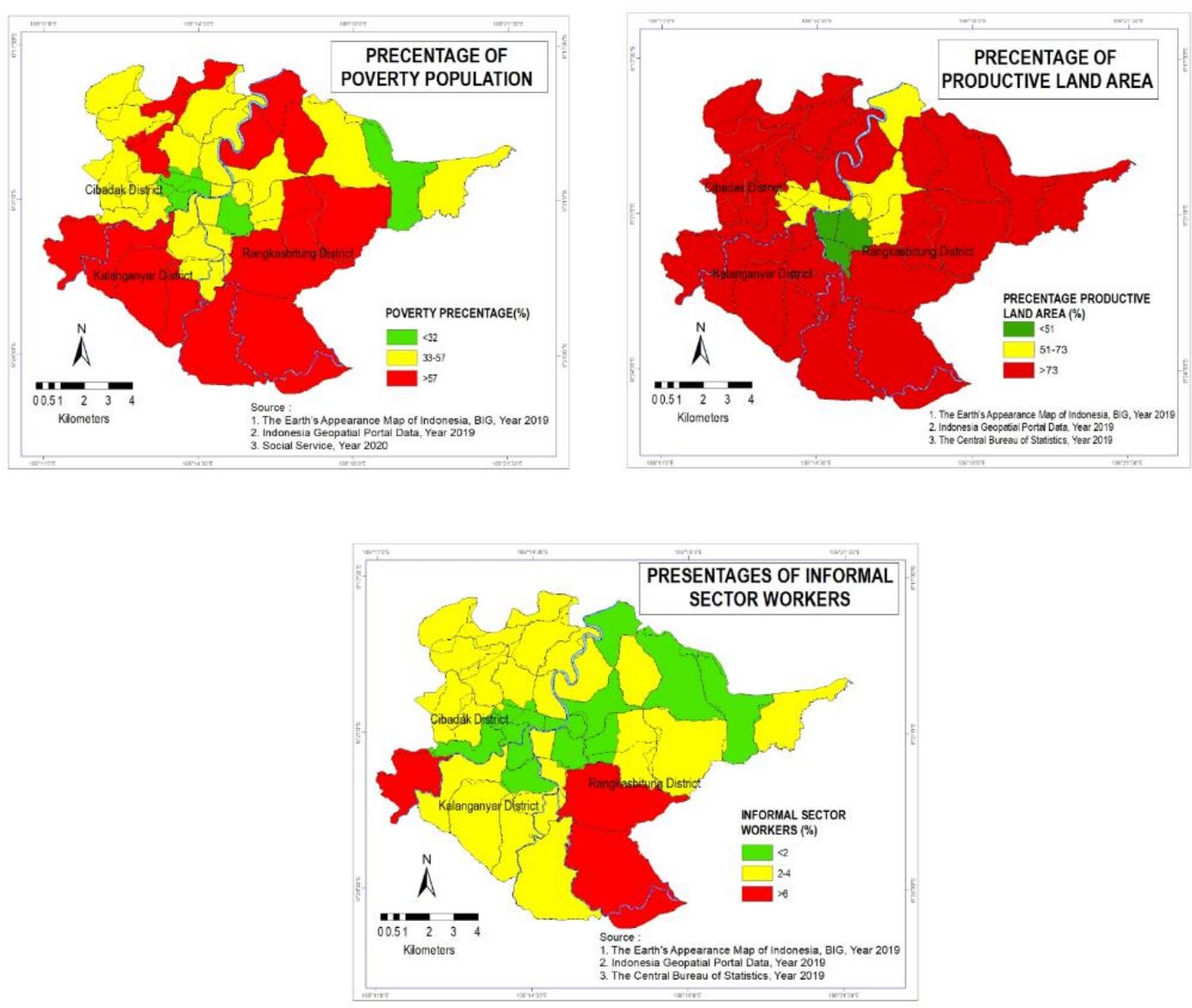

Fig. 6. Parameters of economic vulnerability

\subsection{Flood vurnerability}

Parameters in social vulnerability classification are population density, old age population, toddler age population, female population, and disabled population. Parameters in the classification of economic vulnerability are population poverty, productive land, and informal sector workers. Parameters in physical vulnerability classification are building density, critical facilities, uninhabitable houses, and electricity infrastructure. 
Table 3. Mean value of parameters and standard deviation

\begin{tabular}{|l|c|c|}
\hline \multicolumn{1}{|c|}{ Parameter } & Mean & Standar Deviation \\
\hline $\begin{array}{l}\text { Building Mean Value } \\
\text { Of Building Density }\end{array}$ & 1.3 & 0.3 \\
\hline Toddler Age Population & 9.8 & 1.8 \\
\hline Old Age Population & 5.4 & 2.0 \\
\hline Population Density & 33.1 & 45.3 \\
\hline Electricity Infrastrcture & 0.9 & 0.3 \\
\hline Uninhabitable House & 10.5 & 6.8 \\
\hline Informal Sector Workers & 2.5 & 1.6 \\
\hline Productive Land Area & 78.8 & 16.7 \\
\hline Poverty Population & 51.7 & 17.3 \\
\hline Disabeled Population & 0.4 & 0.3 \\
\hline Female Population & 48.6 & 0.6 \\
\hline Critical Facilities & 2.5 & 2.5 \\
\hline
\end{tabular}

Table 4. Cluster Parameter Average Value

\begin{tabular}{|l|c|c|c|c|c|c|c|}
\hline \multirow{2}{*}{ Parameter } & \multicolumn{7}{|c|}{ Cluster } \\
\cline { 2 - 8 } & $\mathbf{1}$ & $\mathbf{2}$ & $\mathbf{3}$ & $\mathbf{4}$ & $\mathbf{5}$ & $\mathbf{6}$ & $\mathbf{7}$ \\
\hline $\begin{array}{l}\text { Building Mean Value } \\
\text { Of Building Density }\end{array}$ & 1.1 & 1.1 & 1.1 & 2.0 & 1.1 & 1.4 & 1.2 \\
\hline Toddler Age Population & 11.5 & 10.0 & 9.9 & 9.8 & 1.0 & 9.7 & 10.0 \\
\hline Old Age Population & 5.8 & 7.0 & 5.3 & 6.2 & 0.4 & 3.0 & 6.5 \\
\hline Population Density & 10.5 & 218.0 & 17.4 & 77.2 & 121.0 & 28.0 & 18.0 \\
\hline Electricity Infrastrcture & 0.0 & 1.0 & 1.0 & 1.0 & 1.0 & 1.0 & 1.0 \\
\hline Uninhabitable House & 16.3 & 4.0 & 9.1 & 3.6 & 16.0 & 6.7 & 16.4 \\
\hline Informal Sector Workers & 3.0 & 2.0 & 3.2 & 1.4 & 3.0 & 1.3 & 2.1 \\
\hline Productive Land Area & 87.5 & 85.0 & 85.3 & 42.2 & 91.0 & 79.7 & 81.0 \\
\hline Poverty Population & 68.5 & 68.0 & 52.9 & 35.2 & 61.0 & 34.3 & 54.3 \\
\hline Disabeled Population & 0.6 & 0.9 & 0.2 & 0.2 & 0.0 & 0.3 & 0.6 \\
\hline Female Population & 48.3 & 48.0 & 48.6 & 48.8 & 48.0 & 47.7 & 49.0 \\
\hline Critical Facilities & 1.8 & 1.0 & 1.4 & 6.2 & 1.0 & 4.3 & 2.5 \\
\hline \multicolumn{1}{|c|}{ SUM } & $\mathbf{2 5 4 . 7}$ & $\mathbf{4 4 6 . 0}$ & $\mathbf{2 3 5 . 4}$ & $\mathbf{2 3 3 . 8}$ & $\mathbf{3 4 4 . 5}$ & $\mathbf{2 1 7 . 3}$ & $\mathbf{2 4 2 . 5}$ \\
\hline
\end{tabular}

After being processed with the K-Means Cluster, all of the above parameters have a mean and standard deviation, as shown in Table 3. The cluster of regional vulnerability to flooding is divided into three classes: low, moderate, and high. After conducting further analysis, it was found that the low class is in cluster 6 , the moderate class is cluster 3 and cluster 4 , and the high class is cluster 1 , cluster 2 , cluster 5 , and cluster 7 . Areas with low vulnerability classes are found in 2 villages or $8 \%$ of villages' total number. Medium vulnerability classes exist in 22 villages or $58 \%$ of the total number of villages. Meanwhile, the high vulnerability class is found in 14 villages or $37 \%$ of the villages' total number. 


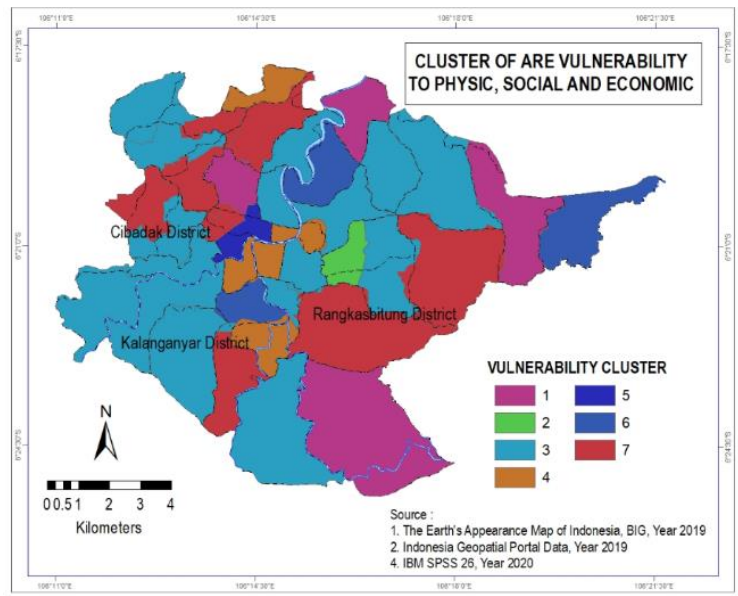

Figure 7 Cluster All Parameters

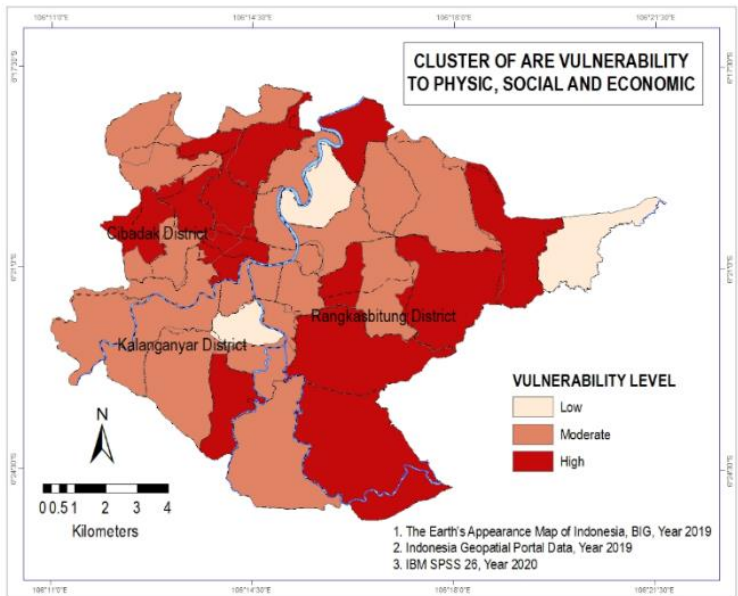

Figure 8 Flood Vulnerability

As previously explained, the areas with a high vulnerability level are cluster 1 , cluster 2 , cluster 5, and cluster 7. This can be seen from the total average value of each parameter (Table 4). Also, based on the flood vulnerability analysis results, it can be seen that not all areas with high flood vulnerability also have high flood-hazard areas. Several villages have moderate flood vulnerability, but it has a low level on the flood hazard map. This occurred in two villages that were located near the main river but had low vulnerability but the dominant high flood hazard, which is Sukamekarsari and Pabuaran villages. This was because most of these villages had low physical, social, and economic vulnerability data. For example, Pabuaran Village in physical vulnerability has a low percentage of uninhabitable houses and critical facilities. Likewise, Sukamekarsari Village in physical vulnerability has a percentage of unfit for habitation and moderate critical facilities, but on the parameter of population density, Sukamekarsari Village has low data. Where high flood hazard areas are known to be near major river flows. These results can later be used to assess the level of flood risk in each village in future studies. This is because the area has moderate physical and socio-economic vulnerability values.

Areas with high flood vulnerability need to be carried out more optimally regarding flood management for the community. This matter makes people live in flood-prone areas more aware of the importance of flood disaster management. Moreover, society can also carry out activities that can reduce the intensity of flooding, such as not littering, especially into rivers, planting forests on barren land, and making absorption holes. In this case, the community has a role in handling floods, and the local government, which is expected to build a reservoir, especially in areas with high flood vulnerability, to accommodate the flow and an effective pumping system.

\section{Conclusion}

The three sub-districts studied, namely Cibadak, Kalanganyar, and Rangkasbitung Districts, are dominated by different flood-prone levels. As seen from the map of the flood hazard view, the dominant study area with moderate flooding is in the middle of the study area. At the same time, high vulnerability levels are scattered in the eastern and western parts of the study area. Based on the clustering analysis using the K-means clustering method, the area's vulnerability to flooding is dominated by Cibadak, Kalanganyar, and Rangkasbitung 
Districts, which are dominated by moderate vulnerability as many as 18 villages or $58 \%$ of the total villages. High levels of vulnerability occurred in 14 villages or $37 \%$ of the total villages. Although there are villages that have a high level of flood hazard, the flood vulnerability has a low level of vulnerability, meaning that the village has physical, social, and economic vulnerability parameters that tend to be low. These results can be used as a basis for determining flood-prone areas in future studies.

\section{Acknowledgements}

This research is one of the requirements for graduation in the Department of Geography, Faculty of Mathematic and Natural Science, University of Indonesia. The authors would like to thank the Directorate of Research and Community Engagement (DPRM) University Indonesia for the research funding in 2020 No. NKB-964/UN2.RST/HKP.05.00/2020.

\section{References}

1. S. N. Willner, C. Otto, and A. Levermann, Nat. Clim. Chang. 8, 594 (2018)

2. M. P. Tambunan and K. Marko, in IOP Conf. Ser. Earth Environ. Sci. 561, (2020)

3. K. Marko, E. Kusratmoko, M. P. Tambunan, and R. Pahlevi, in IOP Conf. Ser. Earth Environ. Sci. 338, (2019)

4. H. Taris, M. P. Tambunan, and K. Marko, in IOP Conf. Ser. Earth Environ. Sci. 311, (2019, August).

5. K. Marko, A. Elfeki, N. Alamri, and A. Chaabani, In Conference of the Arab. J. Geosci., 265 (Springer, Cham, 2018).

6. Economic and Social Commission for Asia and The Pacific (ESCAP), Overview of Natural Disasters and Their Impacts in Asia and The Pacific, 1970-2014, (2015).

7. E. Runtunuwu and H. Pawitan, Hydrometeorological monitoring network of Java Island and hydrologic characteristics of the major river basins, In Proceedings of International Workshop on Integrated Watershed Management for Sustainable Water Use in a Humid Tropical Region, JSPS-DGHE Joint Research Project, Tsukuba, October 2007. Bull. TERC, Univ. Tsukuba, (2008)

8. BPSK Rangkasbitung, Statistik Daerah Kecamatan Rangkasbitung Tahun 2016, (2016).

9. Tambunan, M. P., \& Marko, K. (2020, August). Loss levels regarding flood affected areas in the upper Citarum Watershed. In IOP Conference Series: Earth and Environmental Science (Vol. 561, No. 1, p. 012027). IOP Publishing.

10. H. Xu, C. Ma, J. Lian, K. Xu, and E. J. Chaima, Hydrol. 563, 975 (2018).

11. S. Stafford and J. Abramowitz, Nat. Hazards 85, 1089 (2017)

12. P. Fernandez, S. Mourato, M. Moreira, and L. Pereira, Phys. Chem. Earth Parts A/B/C 94, 47 (2016)

13. F. Renard, Geomatics, Nat. Hazards Risk 8, 525 (2017)

14. L. J. Leis and S. Kienberger, Sustain. 12, 6458 (2020).

15. H. K. Lee, Y. H. Bae, J. Y. Son, and W. H. Hong, Sustain. 12, 4727 (2020)

16. BPBD, Lebak. http://bpbd-lebak.com/kejadian.php (2019).

17. B. N. P. Bencana, Rencana Nasional Penanggulangan Bencana 2015-2019 (BNPB, Jakarta, 2014).

18. S. Susilowati and T. S. NR, Media Teknik Sipil 6, 35 (2006)

19. W. Xu and Y. Peng, Water Sci. Tech. 71, 1507 (2015)

20. A. P. Windarto, Int. J. Artif. Intell. Res. 1, 26 (2017).

21. The Earth's Appearance Map of Indonesia, BIG, 2019. 
22. Indonesia Geopatial Portal Data, (2019).

23. Badan Nasional Penanggulan Bencana. Accessed at https://bnpb.cloud/dibi/ on September 27, 2020. 